\title{
Settlement and juvenile habitat of the European spiny lobster Palinurus elephas (Crustacea: Decapoda: Palinuridae) in the western Mediterranean Sea*
}

\author{
DAVID DÍAZ ${ }^{1}$, MARC MARÍ ${ }^{2}$ PERE ABELLÓ ${ }^{1}$ and MONTSERRAT DEMESTRE ${ }^{1}$ \\ ${ }^{1}$ Institut de Ciències del Mar (CMIMA-CSIC), Passeig Marítim de la Barceloneta 37-49, 08003 Barcelona, Spain. \\ E-mail: ddiaz@icm.csic.es \\ ${ }^{2}$ Departament d'Ecologia, Facultat de Biologia, Universitat de Barcelona, Avinguda Diagonal 645, \\ 08028 Barcelona, Spain.
}

\begin{abstract}
SUMMARY: Settlement characteristics, like timing, depth, microhabitat and density of European spiny lobster Palinurus elephas are described for the very first time. Regular SCUBA-diving surveys were conducted from July 1998 to January 2000 on rocky bottoms of three different geologic origins to assess substratum-dependent differences in recruitment density. Settlement of pueruli took place in June-July, a few weeks after sea surface temperature started to rise. The highest density of juveniles was found at 10-15 m depth. Most spiny lobsters settled in limestone rocks, into empty holes of the date mussel Lithophaga lithophaga, which provided daytime refuge. As they grew, individuals were increasingly found in larger holes and crevices of the rock surface. Sizes were estimated from photographs taken at night when the animals were actively foraging. The smallest observed individuals measured 7.5-8 mm carapace length (CL), but they reached 15-18 mm $\mathrm{CL}$ at the end of October. The consequences of our results for the management of the spiny lobster populations in the northwestern Mediterranean are summarily discussed.
\end{abstract}

Key words: settlement, recruitment, spiny lobster, Palinurus elephas, western Mediterranean Sea.

\section{INTRODUCTION}

Spiny lobsters (Crustacea: Decapoda: Palinuridae) are characteristic species of reef and rocky shores in tropical and temperate seas. From an ecological point of view, their size, abundance and location in the trophic web position them at a key point within the benthic ecosystem (Cobb and Phillips, 1980; Phillips et al., 1994). They constitute one of the most valuable fishery resources world-wide. As a consequence of their importance, the fishing pressure on their populations is often strong and needs appropriate management to reach the goal of sus-

*Received January 22, 2001. Accepted May 16, 2001. tainable exploitation (Phillips et al., 1994). Given the long duration of their planktonic larval life (Booth and Phillips, 1994), the success of settlement is one of the most important key factors in determining the dynamics of spiny lobster populations. Paradoxically, the ecology of the postlarvae is poorly known (Kanciruk, 1980; Phillips and Sastry, 1980; Booth and Phillips, 1994), except for a few selected species like Panulirus argus in the Caribbean, P. cygnus from western Australia, and Jasus edwardsi in New Zealand (Herrnkind et al., 1994), since most of the studies have traditionally placed their emphasis on the adult characteristics (reproduction, growth, dynamics, movements and migrations, etc.). 
The European spiny lobster, Palinurus elephas (Fabricius, 1787), is distributed throughout the Mediterranean Sea and the north-east Atlantic ocean between Morocco and Scotland-South of Norway (Gamulin, 1955; Hepper, 1977; Ceccaldi and Latrouite, 1994; Hunter, 1999). Its populations are known to inhabit rocky bottoms from around 10 to $70 \mathrm{~m}$ depth, and exceptionally down to $160 \mathrm{~m}$ (Zariquiey-Álvarez, 1968; Holthuis, 1987, 1991) and are very actively exploited throughout their distribution range (Campillo and Amadei, 1978; Campillo, 1982; Ceccaldi and Latrouite, 1994). Despite their ecological and commercial importance, however, few studies have been performed on the ecology of their populations either in the Mediterranean or in the north-east Atlantic (Hunter et al., 1996; Hunter, 1999).

The ecology of post-settled juvenile European spiny lobsters is poorly known. Indeed, Hunter (1999) stated that "Pueruli and postpueruli records are rare, and juveniles are seldom observed" and that "... the life of postlarvae and juveniles through to adulthood remains almost entirely unobserved". Bouvier (1913a, b; 1914) first recorded the occurrence of a puerulus of Palinurus elephas from southern England. Since Bouvier's description, very few records of pueruli of $P$. elephas have been documented. Santucci (1926) recorded two specimens in the Tyrrhenian Sea, and Caroli (1946) also obtained one specimen in the Gulf of Naples. Additional records from fish gut contents were reported by Fage (1927) and Légendre (1940) in the Atlantic. The first benthic juvenile stage was described by
Santucci (1926) from a specimen collected in Sicily in July, and Marin (1987) recorded two specimens in Corsica in August. However, as Campillo and Amadei (1978) noted and Hunter (1999) emphasised, the ecology and life history traits of the previously elusive post-larvae and juveniles have not been described.

The main objective of the present study consisted in determining the settlement characteristics of the European Spiny Lobster (Palinurus elephas) by delimiting its seasonality, depth of settlement, microhabitat and juvenile growth patterns.

\section{MATERIAL AND METHODS}

\section{Study area}

Four locations were selected to assess settlement characteristics: one in calcareous limestone rock, two in metamorphic calcareous substrate and one in metamorphic siliceous rock (Fig. 1). The limestone site (CAL), which was selected as the main study area, was located near the town of L'Estartit. It is formed by calcareous rock from the Triassic to lower Cretaceous periods (Llompart and Pallí, 1984). The two metamorphic calcareous sites (METCAL-1 and METCAL-2), from the CambrianOrdovician (Medialdea et al., 1989), were located 8 and $10 \mathrm{~km}$ south of the main site respectively. The siliceous metamorphic site (METSIL) was located $30 \mathrm{~km}$ north of the main site and was also formed by Cambrian-Ordovician rocks (Medialdea et al.,

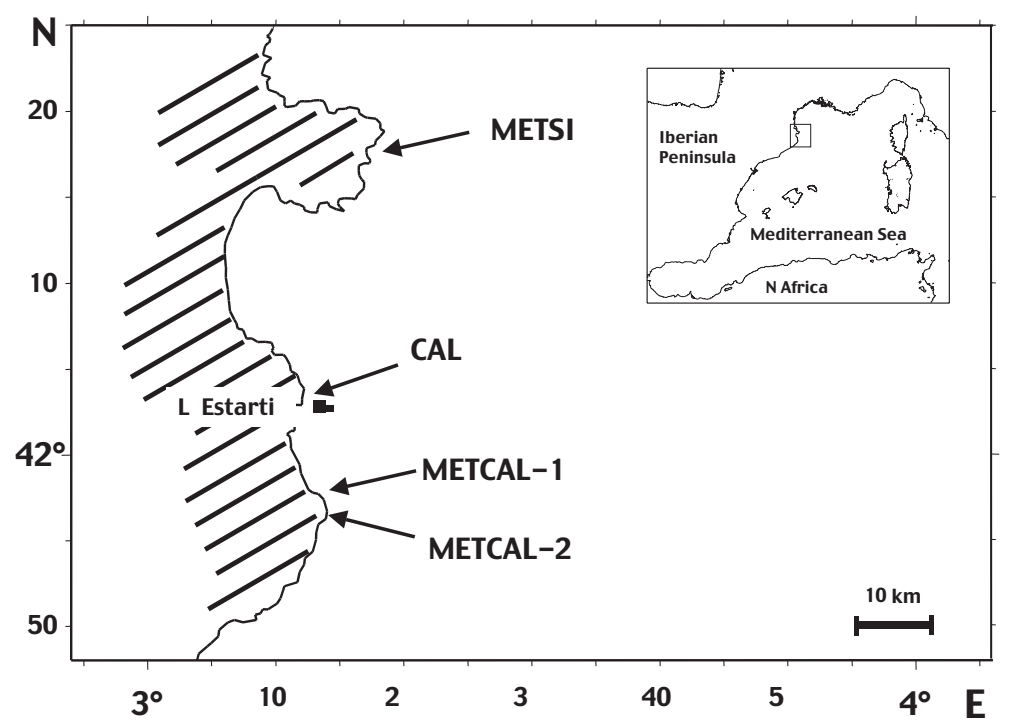

FIG. 1. - Location of the main study area (CAL) and additional comparative areas (METSIL, METCAL-1 and METCAL-2) in the western Mediterranean Sea 
1989). The overall characteristics of the study sites were similar, since they encompassed rocky bottoms of gentle slope provided with scattered large rocks.

\section{Survey methodology}

Exploratory dives were performed down to $50 \mathrm{~m}$ depth. From these preliminary dives, it was observed that recruitment was concentrated at depths of less than $20 \mathrm{~m}$, but was not exclusive to these areas. Our observations suggested that some recruitment may occur at deeper levels at densities far lower than those recorded at depths of less than $20 \mathrm{~m}$. Regular observations were subsequently conducted down to a maximum depth of $20 \mathrm{~m}$.

Sampling was undertaken from July 1998 to January 2000 at the main study site (CAL), which encompassed an estimated thorough area of $350 \mathrm{~m}^{2}$. Sampled areas were distributed in $5 \mathrm{~m}$ depth intervals as follows: $35 \mathrm{~m}^{2}$ at $0-5.0 \mathrm{~m}, 133 \mathrm{~m}^{2}$ at $5.1-10.0$ $\mathrm{m}, 129 \mathrm{~m}^{2}$ at $10.1-15.0 \mathrm{~m}$, and $53 \mathrm{~m}^{2}$ at $15.1-20.0 \mathrm{~m}$. Sampling was undertaken at weekly intervals from July to September 1998 and from May to October 1999, and at bi-weekly intervals during the remaining months.

Numbers of recently-settled juvenile spiny lobsters were visually censused by SCUBA-diving over fixed tracks. Antennae protruding from the holes or crevices on the rock surface (Diaz et al., 2001) helped to locate the smaller individuals. The following characteristics were recorded for each individual observed: depth (with a $0.1 \mathrm{~m}$ precision), inclination (in $45^{\circ}$ intervals; Fig. 2), and type of shelter occupied: (a) date mussel (Lithophaga lithophaga) hole (much deeper than wider and with a rounded mouth and a smooth inner surface) or (b) natural crevice, irregular in shape and lacking a smooth inner surface. All individuals were left untouched.

In order to analyse possible differences in recently-settled juvenile spiny lobster densities with substrate type, specific surveys were performed during the first week of August 1999 (after the peak settlement had taken place) at 10-15 m depth (the depth range of maximum settlement density according to the results of the previous year) at the four study sites: one siliceous metamorphic rock area (METSIL), two calcareous metamorphic areas (METCAL-1 and METCAL-2) and the limestone (CAL) main study area. Three transects were performed at every site to obtain replicates of the spiny lobster densities. The total area surveyed in the different metamorphic rock sampling sites was the following:

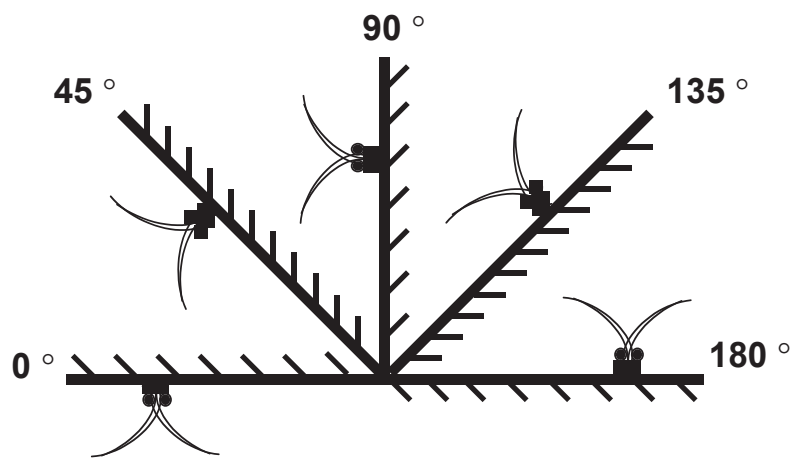

FIG. 2. - Scheme of the different inclinations on the substrate recorded for recently-settled juvenile spiny lobsters Palinurus elephas

METCAL-1: $262 \mathrm{~m}^{2}$; METCAL-2: $175 \mathrm{~m}^{2}$; METSIL: $252 \mathrm{~m}^{2}$. Mean densities of settled individuals among the different sites were compared with an ANOVA test.

A G-test (Sokal and Rohlf, 1981) was performed to test for differences between the observed number of individuals located at the different inclination intervals and the expected number according to the available proportion of the different inclinations in the study area.

Recently-settled spiny lobsters were only observed outside their shelters during the night. In order to estimate size, surveys were performed at night and all individuals detected were photographed beside a millimetric scale. The carapace length $(\mathrm{CL}$, in $\mathrm{mm})$ was later estimated from the photograph by measuring it in relation to the scale with an image analysis system.

Densities of Lithophaga lithophaga holes in the different study areas were estimated by counting the number of date mussel holes on the surface of the rock in randomly selected quadrats of $25 \times 25 \mathrm{~cm}$. Mean densities were compared with an ANOVA test.

Temperature was measured at 0.5, 5, 20, 35, 50, 65 and $80 \mathrm{~m}$ depth daily during the summer and every two-three days, weather permitting, during the rest of the year (J. Pascual, pers. comm.) at a fixed point $1 \mathrm{~km}$ off the Medes Islands, close to the main study site.

\section{RESULTS}

\section{Timing and depth of settlement}

Settlement started in May-June and was only observed in 1999, since sampling in 1998 began when settlement had already started. In both years, 

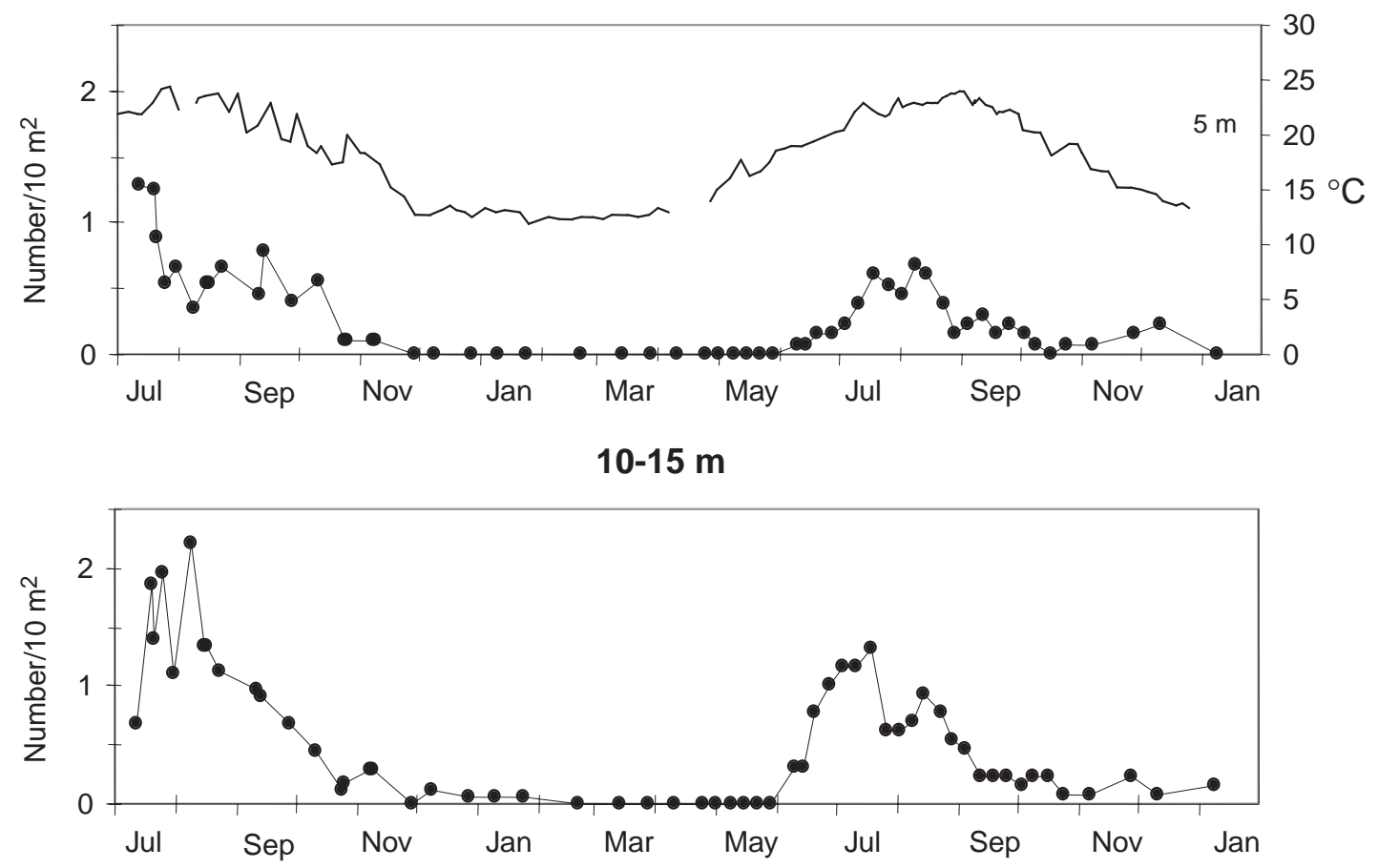

$15-20 \mathrm{~m}$

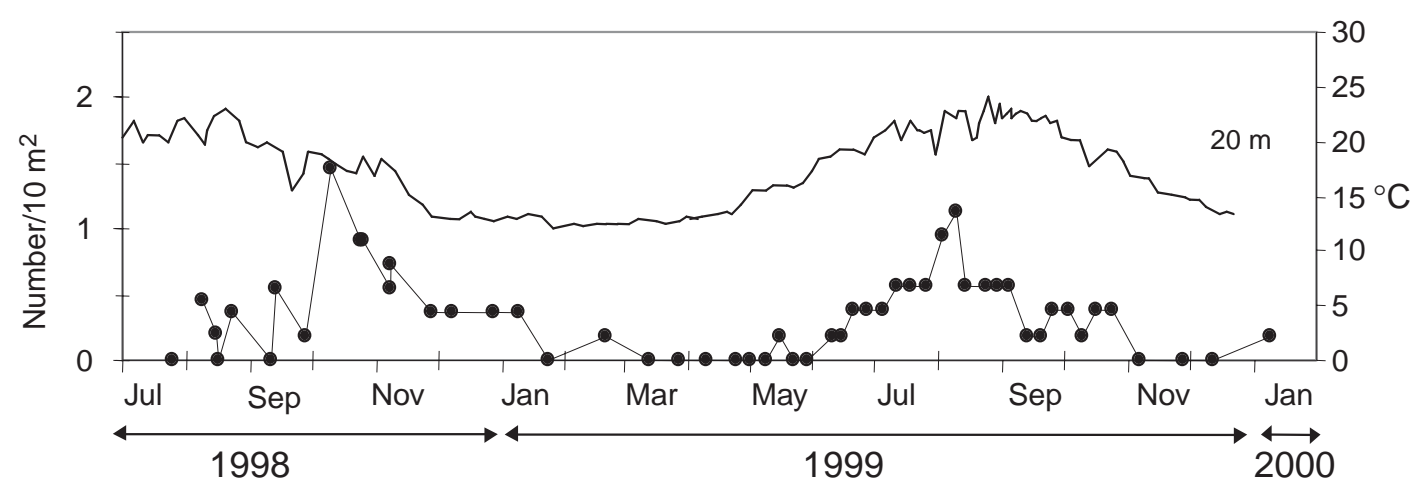

FIG. 3. - Densities (number per $10 \mathrm{~m}^{2}$ ) in the CAL area of juvenile spiny lobsters Palinurus elephas (dots) along the study period (July 1998January 2000) within three depth intervals: $5-10 \mathrm{~m}, 10-15 \mathrm{~m}$, and $15-20 \mathrm{~m}$. Temperature at 5 and $20 \mathrm{~m}$ depth is shown (continuous line).

peak densities of recently-settled juveniles were observed in July to early August, within the 10-15 m depth stratum, reaching average densities of 1.5-2 ind $10 \mathrm{~m}^{-2}$.

Figure 3 depicts observed densities of juvenile $P$. elephas at three depth intervals $(5-10 \mathrm{~m}, 10-15 \mathrm{~m}$, $15-20 \mathrm{~m}$ ) throughout the study period (July 1998January 2000); water temperature in the Medes Islands Marine Reserve at 5 and $20 \mathrm{~m}$ depth is also shown. No recently-settled postpueruli were ever detected within the 0-5 m depth stratum.

The changes in density over time were similar at both the 5-10 m and 10-15 m depth strata in both years. Starting in May-June, numbers peaked in late July to early August, and gradually decreased until
November; thereafter, only occasional individuals were observed until the following season. By contrast, at 15-20 m, densities increased from August to October during the first season studied, then decreased gradually before disappearing in February-March. The pattern during the second year studied was similar to that observed at 10-15 m. Interannual variability in settlement densities was observed between the two seasons. In 1999 peak settlement densities (1.2 ind $10 \mathrm{~m}^{-2}$ ) were $40 \%$ lower than in the previous season $\left(2.0\right.$ ind $\left.10 \mathrm{~m}^{-2}\right)$. Settlement activity apparently took place in several discrete periods, as suggested by the occurrence of several peaks and by the steepness of the slopes in the densities of recently-settled postpueruli with time. 


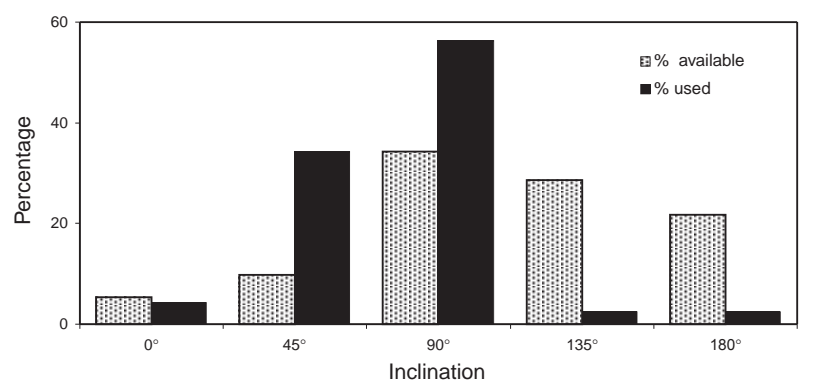

FIG. 4. - Proportion of available substrate by inclination range (total surface: $347 \mathrm{~m}^{2}$ ) and proportion of recently settled individuals found in the different inclination ranges $(n=396)$.

\section{Settlement microhabitat}

Figure 4 shows the proportion of recently settled postpueruli in relation to substrate inclination, and the proportion of substrate available by inclination range (see Fig. 2). The observed number of juvenile spiny lobsters found at the different inclination ranges was significantly different $(\mathrm{G}$-test, $\mathrm{p}<0.001)$ from the expected number according to the actual availability of substrate. Thus, juvenile spiny lobsters were significantly found in greater than expected proportions on inclinations of $90^{\circ}$ and $45^{\circ}$, that is, in sciaphilous vertical sections and slightly overhanging rocks. Conversely, they were found in lesser than expected proportions in photophilous rock surfaces facing the sea surface.

Most of the recently-settled juveniles detected during the study were located within empty holes bored in the rock by the endolithic bivalve Lithophaga lithophaga (Fig. 5). This microhabitat appears as almost the exclusive shelter for early juvenile spiny lobsters in the study area, since percentage use of this type of habitat during the two settlement seasons studied (1998-1999) ranged between 91 and

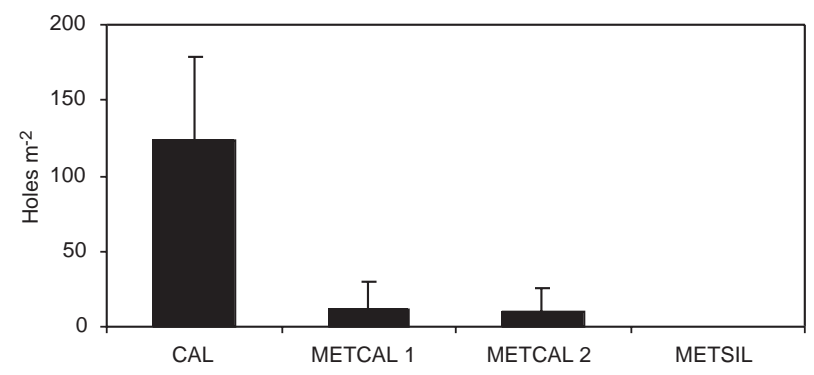

FIG. 6. - Mean density of date mussel holes Lithophaga lithophaga (holes $/ \mathrm{m}^{2}$ ) at $10-15 \mathrm{~m}$ depth in the three metamorphic rock areas (METSIL, METCAL-1 and METCAL-2) and in the sedimentary non-metamorphosed calcareous rock study area (CAL).

$100 \%$ during the settlement period: June-July. Irregular and larger crevices progressively replaced date mussel holes as refuges, as juvenile lobsters increased size when moulting.

\section{Settlement variability in relation to substrate type}

Figure 6 represents densities of Lithophaga lithophaga holes in relation to substrate types (see also Table 1). The mean number of L. lithophaga holes per square metre was significantly higher by an order of magnitude $(\mathrm{p}<0.001)$ in the calcareous area $\left(124.0\right.$ holes $\left.\mathrm{m}^{-2}\right)$ than in the metamorphic calcareous areas (11.4-13.3 holes $\mathrm{m}^{-2}$ ). No date mussel holes were observed in the metamorphic siliceous rock area.

As a logical consequence of previous correlates both between settlers density and date mussel holes and between date mussel holes and limestone rocks, the mean density of juvenile spiny lobsters at the limestone rock site (0.66 individuals $10 \mathrm{~m}^{-2}$; Fig. 7) was significantly higher $(F(3,8)=17.39 ; \mathrm{p}<0.0007)$

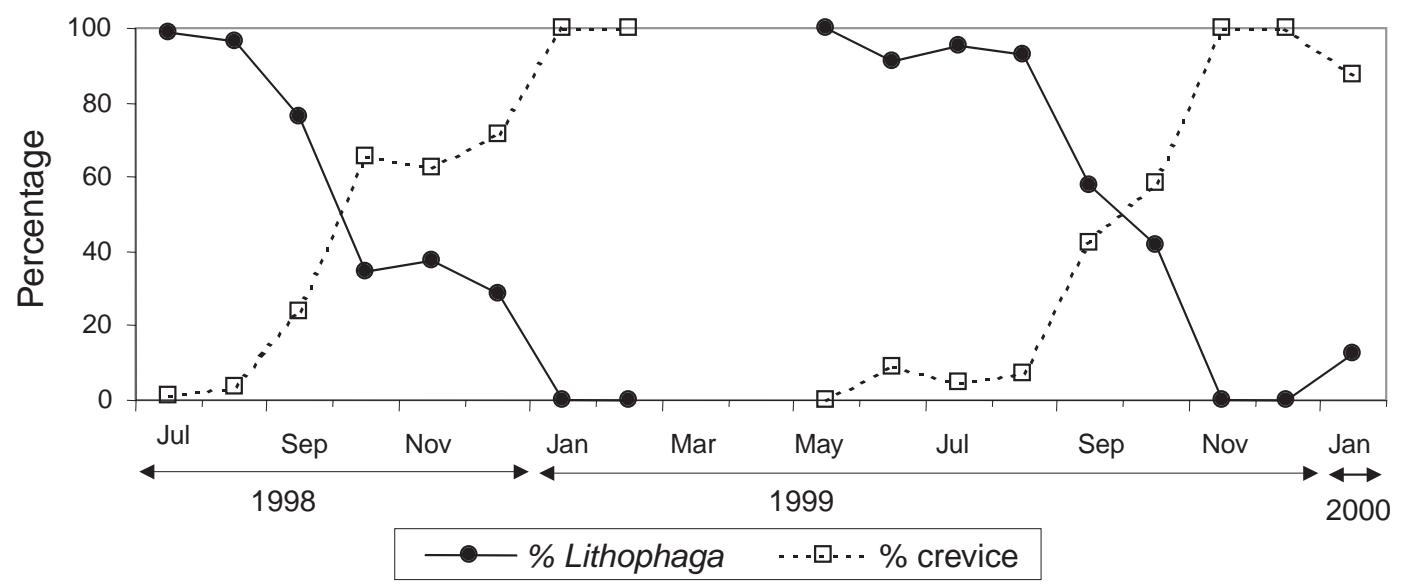

FIG. 5. - Proportion of the juvenile lobster Palinurus elephas population using date mussel Lithophaga lithophaga holes or crevices in the rock (July 1998-October 1999) in the CAL area. 
TABLE 1. - Mean number of date mussel holes Lithophaga lithophaga at 10-15 m depth in four sampling localities (CAL: Non-metamorphic calcareous rock; METCAL: metamorphic calcareous rock; METSIL: metamorphic siliceous rock).

\begin{tabular}{|c|c|c|c|c|}
\hline Substrate type & CAL & METCAL-1 & METCAL-2 & METSIL \\
\hline Area surveyed $\left(\mathrm{m}^{2}\right)$ & 5.25 & 4.50 & 5.06 & 4.69 \\
\hline Mean $L$. lithophaga holes / $\mathrm{m}^{2}$ & 124.0 & 13.3 & 11.4 & 0.0 \\
\hline S.D. & 54.0 & 23.1 & 17.9 & - \\
\hline Number of quadrat replicates & 84 & 72 & 81 & 75 \\
\hline
\end{tabular}

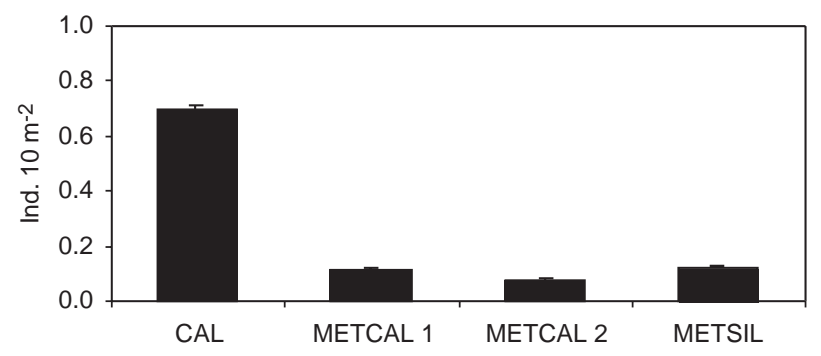

FIG. 7. - Densities of recently-settled juvenile spiny lobsters Palinurus elephas at $10-15 \mathrm{~m}$ depth in the first week of August in the three metamorphic rock areas (METSIL, METCAL-1 and METCAL-2) and in the sedimentary non-metamorphosed limestone calcareous rock study area (CAL).

than the densities at the metamorphic sites, either calcareous or siliceous $(0.11,0.08$ and 0.12 individuals $10 \mathrm{~m}^{-2}$ respectively for METCAL-1, METCAL2 and METSIL). Densities between metamorphic sites were not significantly different $(\mathrm{p}>0.050)$.

\section{Juvenile growth}

Sizes of recently-settled individuals (June-July) ranged between 7.5-8 and $14 \mathrm{~mm} \mathrm{CL}$ (Fig. 8). In 1998, median sizes of juvenile spiny lobsters increased from $11 \mathrm{~mm} \mathrm{CL}$ in late July to $19 \mathrm{~mm}$ CL in late October. In 1999, median sizes increased from $9 \mathrm{~mm}$ CL in early July to $17 \mathrm{~mm}$ CL in mid October. The smallest individuals were detected at approximately monthly intervals, thus reinforcing the suggestion of settlement taking place in several discrete periods throughout the season.

\section{DISCUSSION}

The spiny lobster Palinurus elephas has been a highly targeted species since ancient times (Aristotle provided an accurate description in the 4th century B.C.) all around the heavily populated Mediterranean coasts. Probably due to high market prices, the possibility of a decent catch, however remote, has been sufficient incentive for unremitting exploitation of this resource. It is consequently overfished to extraordinarily low levels in terms of both growth and recruitment overfishing. As is now recognised for a great deal of coral reef fishes (Doherty, 1982; Victor, 1983; Doherty and Fowler, 1994), spiny lobster populations in the Mediter-

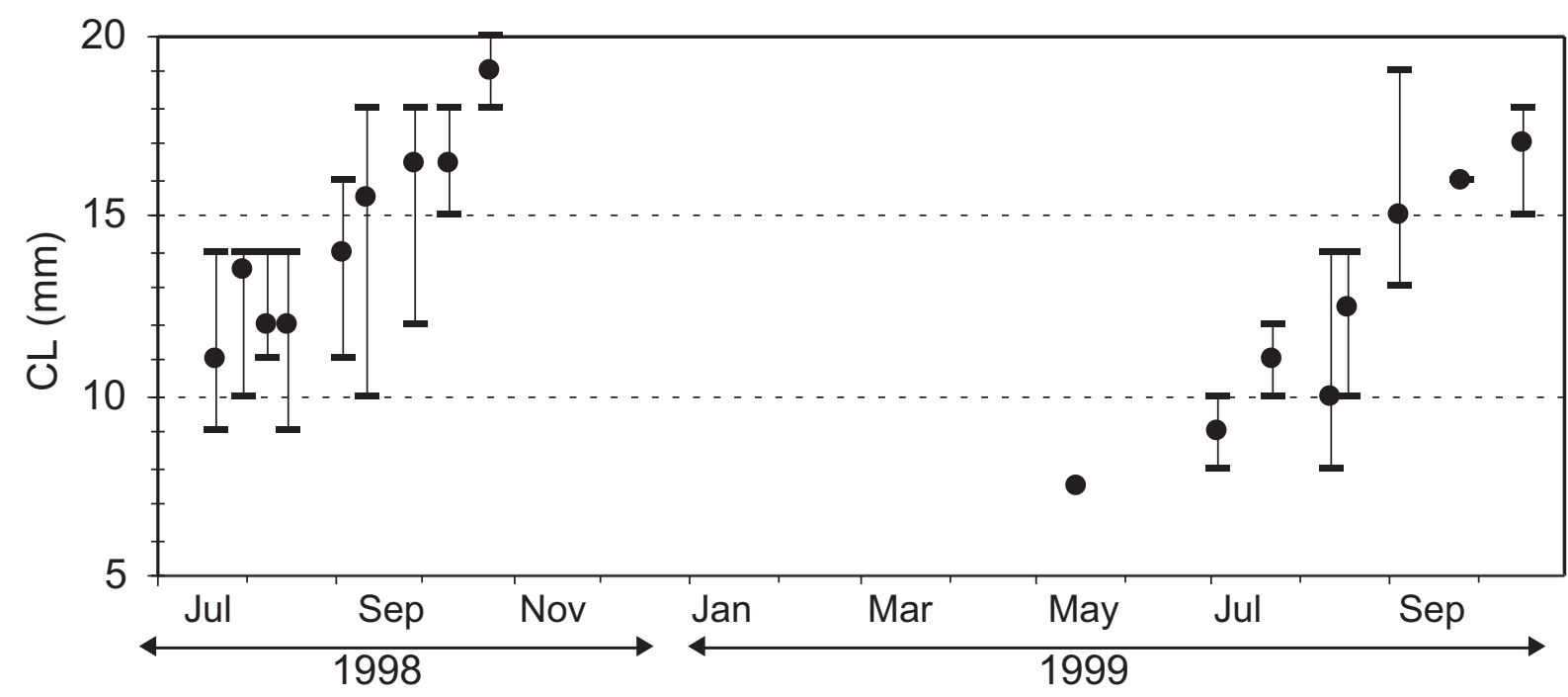

FIG. 8. - Median size and size range of juvenile spiny lobsters Palinurus elephas during the study period (July 1998-January 2000). 
ranean may be far from their carrying capacities, but are rather limited by the number of individuals that settle out of the plankton. As recruitment overfishing (reduction of population size causing reduced egg production and increased chance of recruitment failure) is detected in a growing number of fished populations, the importance of recruitment analyses for management decisions to ensure the maintenance of sufficient adults in exploited populations increases.

With the previous considerations in mind, the present study set out to provide useful information on the settlement characteristics of the European spiny lobster occurring in the study area, both for population management and for the knowledge of the benthic processes. It has identified, described and delimited the main settlement habitat and the seasonality of settlement of P. elephas in the western Mediterranean, hitherto unknown for any sector of its distribution area.

As shown by our results, settlement in P. elephas takes place within a limited temperature window centred in the warmest months, probably reflecting the predominantly tropical/subtemperate distribution of this family (Phillips and McWilliam, 1986; Booth and Phillips, 1994). Settlement started when sea surface temperatures began to increase in midMay, peaked in June-July, when temperatures in the study area had not yet reached the annual maximum (which takes place in August-September) and ended in August. Growth of juvenile spiny lobsters therefore takes place during the warmest summer months. The relatively short settlement period of the European spiny lobster in the western Mediterranean may be one of the critical factors affecting settlement success, since this may be much higher or lower according to the specific interannual environmental variations and settlement synchronising factors. If correlates between settlement and the period of warmest water temperatures might suggest a role for temperature in the settlement success, this role seems to be by no means exclusive. It is worth noting that $P$. elephas currently settles in much cooler waters in its northern distribution limit in the British Isles. Variability in settlement success is probably not only dependent on the temperature at settlement time but also on many other, probably more important, factors, such as larval survival, settlement timing, and mesoscale oceanographic processes carrying the larvae and postlarvae (MacDonald, 1986; Phillips et al., 1991; Booth, 1994; Booth and Phillips, 1994; Briones-Fourzan, 1994). Variability in the strength of the parental stock (recruitment overfishing) is also probably playing a large and relevant role in the variability of settlement success.

Even if settlement activity has been observed to extend for up to two months, there is certainly a more intense settlement activity in two or three discrete periods, with lesser activity in the intervening periods; suggestively, the settlement peaks appeared separated by around a month or a moon cycle. The association of spiny lobster settlement with lunar phases has been known for a time for several species, such as $P$. argus in the Caribbean (e.g. Acosta et al., 1997; Eggleston et al., 1998).

In the Mediterranean populations of P. elephas, egg laying takes place from August to October, the egg carrying period from October to March and hatching (or associated occurrence of first stage phyllosoma larvae in the plankton) from December to March, but mainly in January and February (Gamulin, 1955; Campillo, 1982; Hunter, 1999). Since peak settlement was observed in June-July during the present investigation, the duration of planktonic life of the spiny lobster phyllosomae in the western Mediterranean is confirmed as being approximately five months (Marin, 1985; Hunter, 1999).

A neat preference for a narrow, shallow bathymetric range to settle has been clearly stated. In the area, depths between 10 and $15 \mathrm{~m}$ are strongly preferred by settling larvae, even if algal coverage and date mussel holes extend far above and below of these limits. The observed settlement depth is also much shallower than the depths at which adults are usually found (Campillo and Amadei, 1978; Holthuis, 1987; Ceccaldi and Latrouite, 1994). In the nearby Medes islands marine reserve, adult spiny lobsters are always found deeper than $25 \mathrm{~m}$, mainly at depths of over $40 \mathrm{~m}$. Some larger, juvenile individuals of around 33-39 mm CL (corresponding to the previous year's settlement season) were sometimes observed in the study area, but adults never were. Even if evidences are lacking, this separate distribution between young and adult stages suggests the only possible explanation, which involves the existence of ontogenetic migrations to deeper water with increasing size and age.

Selection of appropriate substrata providing adequate shelter is a key factor in determining survival not only at settlement but also during the early postsettlement of spiny lobsters (Herrnkind and Butler, 1994). Sharp selectivity in the nature of selected substrata is probably the rule, and a wide spectrum of substrata are used around the world depending on 
the species, latitude or habitat. Some species prefer to settle among algae, sea-grasses or mangrove roots, but rocky bottoms are mostly preferred. Holes in rock surfaces have been reported to be used by a wide variety of mobile organisms as a temporary refuge or as a more permanent microhabitat, examples being fish, crabs and stomatopods (Kotrschal, 1988; Moran and Reaka, 1988; Norman et al., 1994; Macpherson and Zika, 1999). Hole utilisation, although not used as the main microhabitat, has been reported for Panulirus versicolor, Panulirus longipes and Panulirus penicillatus (Yoshimura et al., 1994). More precisely, the occupation of holes in rocks as the main juvenile microhabitat has been reported for some exotic spiny lobsters, such as Panulirus japonicus (Yoshimura and Yamakawa, 1988; Yoshimura et al., 1994) and Panulirus cygnus (Jernakoff, 1990). But the most interesting cases are those of Jasus edwardsii (Booth, 1979) and the Japanese spiny lobster P. japonicus (Norman et al., 1994; Norman and Morikawa, 1996) which, similarly to our species, selected the holes of vicarious date mussels and other boring molluscs (pholads) as a preferred microhabitat for settlement.

The identification of date mussel holes in calcareous rock as the main settlement microhabitat of P. elephas has important implications for fishery management, since date mussels are exploited, sometimes heavily, in the Mediterranean, though their collection is officially banned in some countries. They are extracted from the rock by demolishing it, with the consequent destruction of the habitat and the associated benthic community (Russo and Cicogna, 1992; Fanelli et al., 1994). Date mussel extraction undoubtedly leads to a decrease in the availability of the suitable settlement microhabitat for P. elephas. Additionally, date mussels are longlived and have very low growth rates (Kleeman, 1973; Galinou-Mitsoudi and Sinis, 1997) and their exploitation may rapidly become unsustainable (Russo and Cicogna, 1992; Cuccu et al., 1994; Fanelli et al., 1994).

The inclination of the substrate used as day-time shelter indicated that juvenile P. elephas preferred sciaphilous microhabitats. A similar pattern of rock inclination use, in which both pueruli and first instar juveniles preferred holes in sections of the reef with a negative incline, has also been reported for the Japanese spiny lobster, Panulirus japonicus (Norman and Morikawa, 1996). This preference may be related not only to light avoidance, but also to siltation of the holes.
We have identified significant differences in densities of recently-settled juvenile spiny lobsters among geomorphological areas differing in the substrate characteristics. Thus, densities in limestone calcareous rocks were much higher than in metamorphic slate areas, both calcareous and siliceous. The main apparent difference between these substrate types was the occurrence of rock-boring bivalve holes, in particular of the date mussel Lithophaga lithophaga, whose densities were significantly higher in the calcareous area. The empty, unoccupied holes were largely used by juvenile spiny lobsters as a day-time shelter refuge. Predation by starfish seems to be the main cause of natural mortality of date mussels in the study area (unpublished personal observations), in which no human extraction of date mussels takes place.

In some species, settlement appears to exceed the carrying capacity of the habitat, depending on the shortage of available suitable habitat (Kanciruk, 1980; Phillips, 1981; Field and Butler, 1994; Herrnkind et al., 1994). This does not seem to be the case in the present study area, since the availability of date mussel holes greatly exceeds the observed number of settled postpueruli. It could, however, be an important limiting factor in the metamorphic and non-calcareous areas, where settlement is mainly restricted to crevices of the adequate size and shape.

Observations on juvenile spiny lobster behaviour are scarce. In the study area, settled juveniles were nocturnally active and showed a marked fidelity to a single hole (unpublished personal observations), returning there after nocturnal foraging excursions, as is the case for the Japanese spiny lobster, Panulirus japonicus (Yoshimura and Yamakawa, 1988; Norman et al., 1994). No individuals were ever observed out of their shelter holes or crevices during daylight hours, suggesting the occurrence of a strong circadian activity rhythm (Naylor, 1988). Date mussel holes have only one opening. From this hole, settled juvenile spiny lobsters only extrude the antennae, which in addition to bearing chemoreceptors are also used as defensive and stridulative organs (Phillips et al., 1994).

As a concluding remark, the present study has identified the settlement time, depth and main microhabitat of the European spiny lobster Palinurus elephas in a region of the northwestern Mediterranean Sea, a priori representative of a wide proportion of rocky bottoms throughout the western Mediterranean: limestone rocks, calcareous and siliceous metamorphic rocks. This information is 
valuable not only per se, but also for management purposes, since scientifically-based settlement and juvenile habitat protection is now possible.

\section{ACKNOWLEDGEMENTS}

This piece of research was partially funded by the research projects "Seguiment temporal de la Reserva Marina de les Illes Medes" financed by Departament de Medi Natural - Generalitat de Catalunya (PCC 10.05.227.07/5) and "Estudio del hábitat y pautas de asentamiento de la langosta común en la Reserva Marina de las Islas Medas" financed by Ministerio de Ciencia y Tecnología Dirección General de Investigación (REN20000877-C02-01/MAR). We are very grateful to Dr. Mikel Zabala for his valuable comments and support, to Cristina Villena, Raquel Heras and Bernat Hereu for field assistance, and to Dr. Christopher P. Norman for his advice and early suggestions.

\section{REFERENCES}

Acosta, C.A., T.R. Matthews and M.J. Butler. - 1997. Temporal patterns and transport processes in recruitment of spiny lobster (Panulirus argus) postlarvae to south Florida. Mar. Biol., 129: 79-85.

Booth, J.D. - 1994. Jasus edwardsii larval recruitment off the East coast of New Zealand. Crustaceana, 66: 295-317.

Booth, J.D. - 1979. Settlement of the rock lobster, Jasus edwardsii (Decapoda: Palinuridae) at Castlepoint, New Zealand. N. Z. J. Mar. Freshw. Res., 13: 395-406.

Booth, J.D. and B.F. Phillips. - 1994. Early life history of spiny lobster. Crustaceana, 66: 271-294.

Bouvier, E.L. - 1914. Recherches sur le développement postembryonnaire de la langouste commune (Palinurus vulgaris). $J$. mar. biol. Ass. UK, 10: 179-193.

Bouvier, E.L. - 1913a. The post-embryonic development of the spiny lobster. Nature, Lond., 91(2286): 633-634.

Bouvier, E.L. - 1913b. Observations nouvelles sur le développement larvaire de la Langouste commune (Palinurus vulgaris Latr.). C. R. Acad. Sci., 157 (11): 457-463.

Briones-Fourzán, P. - 1994. Variability in postlarval recruitment of the spiny lobster Panulirus argus (Latreille, 1804) to the Mexican Caribbean coast. Crustaceana, 66: 326-340.

Campillo, A. - 1982. Premières données sur la pêche et la biologie de la langouste de Corse, Palinurus elephas Fabricius. Quad. Lab. Tecnol. Pesca, 3(2-5):115-139.

Campillo, A. and J. Amadei. - 1978. Premières données biologiques sur la langouste de Corse, Palinurus elephas Fabricius. Rev. Trav. Inst. Pêches Marit., 42: 347-373.

Caroli, E. -1946. Di un puerulus de Palinurus vulgaris, pescato nel Golfo di Napoli. Pubbl. Staz. zool. Napoli, 20:152-157.

Ceccaldi, H.J. and D. Latrouite. - 1994. The French fisheries for the European Spiny Lobster Palinurus elephas. In: B.F. Phillips, J.S. Cobb and J. Kittaka (eds.), Spiny lobster management, pp.169-178. Fishing News Books, Blackwell Scientific Publications, London.

Cobb, J.S. and B.F. Phillips. - 1980. The Biology and Management of Lobsters. Volume II. Ecology and Management. Academic Press, New York.

Cuccu, D., P. Addis, I. Lenza, M. Stefani and S. Campisi. - 1994. Prime osservazioni sulla distribuzione di Lithophaga lithophaga (Linnaeus 1758) (Bivalvia Mytilidae), lungo le coste sarde.
Biol. Mar. Medit., 1: 399-400.

Díaz, D., M. Marí and P. Abelló. - 2001. Juveniles de langosta. Investigación y Ciencia, 295: 46-47.

Doherty, P.J. - 1982. Some effects of density on the juveniles of two species of tropical, territorial damselfishes. J. Exp. Mar. Biol. Ecol. , 65: 249-261.

Doherty, P. and T. Fowler. - 1994. An empirical test of recruitment limitation in a coral reef fish. Science, 263: 935-939.

Eggleston, D.B., R.N. Lipcius, L.S. Marshall and S.G. Ratchford. 1998. Spatiotemporal variation in postlarval recruitment of the Caribbean spiny lobster in the central Bahamas: Lunar and seasonal periodicity, spatial coherence and wind forcing. Mar. Ecol. Prog. Ser., 174: 33-49.

Fage, L. - 1927. Sur le "stade natant" (puerulus) de la langouste commune (Palinurus vulgaris Latreille). Arch. Zool. exp. gén., 67:32-39.

Fanelli, G., S. Piraino, G. Belmonte, S. Geraci and F. Boero. 1994. Human predation along Apulian rocky coasts (SE Italy): desertification caused by Lithophaga lithophaga (Mollusca) fisheries. Mar. Ecol. Prog. Ser., 110:1-8.

Field, J.M. and M.J. Butler. - 1994. The influence of temperature, salinity, and postlarval transport on the distribution of juvenile spiny lobsters, Panulirus argus (Latreille, 1804), in Florida Bay. Crustaceana, 67: 26-45.

Galinou-Mitsoudi, S. and A.L. Sinis. - 1997. Population dynamics of the date mussel, Lithophaga lithophaga (L., 1758) (Bivalvia: Mytilidae), in the Evoikos Gulf (Greece). Helgoland. Meeresunt., 51: 137-154.

Gamulin, T. - 1955. Contribution à la connaissance de l'écologie de la langouste (Palinurus vulgaris Latr.) dans l'Adriatique. Acta Adriatica, 7: 1-17.

Hepper, B.T. - 1977. The fishery for crawfish, Palinurus elephas, off the coast of Cornwall. J. mar. biol. Ass. U.K., 57: 925-941.

Herrnkind, W.F. and M.J. Butler. - 1994. Settlement of spiny lobsters, Panulirus argus in Florida: pattern without predictability. Crustaceana, 67: 46-64.

Herrnkind, W.F., P. Jerkanoff and M.J. Butler. - 1994. Puerulus and post-puerulus ecology. In: B.F. Phillips, J.S. Cobb and J. Kitta$\mathrm{ka}$ (eds.), Spiny lobster management, pp. 213-229. Fishing News Books, Blackwell Scientific Publications, London.

Holthuis, L.B. - 1991. Marine Lobsters of the World. FAO species catalogue Vol. 13. FAO Fish. Synop., 125(13): 1-292.

Holthuis, L.B. - 1987. Homards, Langoustines, Langoustes et Cigales. In: W. Fischer, M. Schneider and M.-L. Bauchot (eds.), Fiches FAO d'identifications des espèces pour les besoins de la pêche. Méditerranée et Mer Noire. Zone de pêche 37. Révision 1. Volume I Végétaux et Invertébrés, pp. 293-319. FAO, Rome.

Hunter, E. - 1999. Biology of the European spiny lobster, Palinurus elephas (Fabricius, 1787) (Decapoda, Palinuridea). Crustaceana, 72: 545-565.

Hunter, E., S.E. Shackley and D.B. Bennett. - 1996. Recent studies on the crawfish Palinurus elephas in South Wales and Cornwall. J. mar. biol. Ass. U.K., 76: 963-983.

Jernakoff, P. - 1990. Distribution of newly settled western rock lobsters Panulirus cygnus. Mar. Ecol. Prog. Ser., 66: 63-74.

Kanciruk, P. - 1980. Ecology of juvenile and adult Palinuridae (spiny lobsters). In: J.S. Cobb and B.F. Phillips (eds.), The biology and management of lobsters, 2: Ecology and management, pp. 59-96. Academic Press, New York.

Kleemann, K.H. - 1973. Der Gesteinsabbbau durch Ätzmuscheln an Kalkküsten. Oecologia (Berl.), 13: 377-395.

Kotrschal, K. - 1988. Blennies and endolithic bivalves: differential utilization of shelter in Adriatic Blenniidae (Pisces: Teleostei). P.S.Z.N.I: Mar. Ecol., 9: 253-269.

Légendre, R. - 1940. La faune pélagique de l'Atlantique au large du Golfe de Gascogne, recueillie dans des estomacs de Germons. Ann. Inst. Océanogr., 20: 53-58.

Llompart, C. and Ll. Pallí. - 1984. Geologia de les Illes Medes. In: J. Ros, I. Olivella and J.M.Gili (eds.), Els Sistemes Naturals de les Illes Medes, pp. 61-73. Institut d'Estudis Catalans, Barcelona.

MacDonald, C.D. - 1986. Recruitment of the puerulus of the spiny lobster, Panulirus marginatus, in Hawaii. Can. J. Fish. Aquat. Sci., 43: 2118-2125.

Marin, J. - 1987. Exploitation, biologie et dynamique du stock de langouste rouge de Corse Palinurus elephas Fabricius. Ph.D. Thesis, Université d'Aix Marseille II. 
Marin, J. - 1985. La langouste rouge: biologie et exploitation. Pêche marit., 64:105-113.

Macpherson, E. and U. Zika. - 1999. Temporal and spatial variability of settlement success and recruitment level in three blennoid fishes in the northwestern Mediterranean. Mar. Ecol. Prog. Ser., 182: 269-282.

Medialdea, J., A. Maldonado, J.I. Díaz, C. Escutia, M. Farrán, S. Giró, M. Serra, T. Medialdea and A. Vazquez. - 1989. Mapa geológico y memoria explicativa de la Hoja n. 35 (Barcelona) del mapa de la Plataforma Continental Española y zonas adyacentes 1:200.000. I T G E. Servicio de Publicaciones del Ministerio de Industria, Madrid.

Moran, D.P. and M.L. Reaka. - 1988. Bioerosion and the availability of shelter for benthic reef organisms. Mar. Ecol. Prog. Ser., 44: $249-263$

Naylor, E. - 1988. Rhythmic behaviour of decapod crustaceans. Symp. Zool. Soc. Lond., 59: 177-199.

Norman, C.P. and Y. Morikawa - 1996. Rock face incline and height above sea bed of holes used as shelters by pueruli and juvenile Japanese spiny lobsters Panulirus japonicus. Crustacean Research, 25: 121-128.

Norman, C.P., H. Yamakawa and T.Yoshimura. - 1994. Habitat selection, growth rate and density of juvenile Panulirus japonicus (Von Siebold, 1824) (Decapoda, Palinuridae) at Banda, Chiba Prefecture, Japan. Crustaceana, 66: 366-383.

Phillips, B.F. - 1981. The circulation of the southeastern Indian Ocean and the planktonic life of the western rock lobster. Oceanogr. mar. Biol. Ann. Rev., 19: 11-39.

Phillips, B.F., J.S. Cobb and J. Kittaka. - 1994. Spiny Lobster Management. Fishing News Books, Blackwell Scientific Publications, London.

Phillips, B.F., A.F. Pearce and R.T Litchfield. - 1991. The Leewin
Current and larval recruitment to the rock (spiny) lobster fishery off western Australia. J. Royal Soc. West. Austr. ,74: 93-100.

Phillips, B.F. and P.S. McWilliam. - 1986. The pelagic phase of spiny lobster development. Can. J. Fish. Aquat. Sci., 43: 2153 2163.

Phillips, B.F. and A.N. Sastry. - 1980. Larval ecology. In: J.S. Cobb and B.F. Phillips (eds.), The biology and management of lobsters, 2: Ecology and management, pp.11-57. Academic Press, New York

Russo, G.F. and F. Cicogna. - 1992. Il dattero di mare, Lithophaga lithophaga e gli effetti distruttivi della sua pesca sull'ambiente marino costiero: problemi e prospettive. Boll. Mus. Ist. Biol. Univ. Genova, 56-57: 165-194.

Santucci, R. - 1926. Lo stadio natante e la prima forma post-natante dell'aragosta (Palinurus vulgaris Latreille) del Mediterraneo. R. Comm.Tal. Italiana Mem., 127: 1-12.

Sokal, R.R. and F.J. Rohlf. - 1981. Biometry. W.H. Freeman and Co., New York.

Victor, B.C. - 1983. Recruitment and population dynamics of a coral reef fish. Science, 219: 419-420.

Yoshimura, T. and H. Yamakawa. - 1988. Microhabitat and behaviour of settled pueruli and juveniles of the Japanese spiny lobster Panulirus japonicus at Kominato, Japan. J. Crust. Biol., 8: 524-531.

Yoshimura, T., H. Yamakawa and C.P. Norman. - 1994. Comparison of hole and seaweed habitats of post-settled pueruli and early benthic juvenile lobsters, Panulirus japonicus (Von Siebold, 1824). Crustaceana, 66: 356-365.

Zariquiey-Álvarez R. - 1968. Crustáceos decápodos ibéricos. Inv. Pesq., 32: 1-510

Scient. ed.: J.M. Gili 